\title{
Fracture of the femur, fish odour, and copper deficiency in a preterm infant
}

\author{
I BLUMENTHAL, G T LEALMAN, AND P P FRANKLYN \\ Department of Paediatrics, and Department of Radiology, Bradford Royal Infirmary
}

SUMMARY A preterm baby boy with blood and bone changes of copper deficiency is described. Copper deficiency was suspected after fracture of the left femur during examination of the hip joint. A low serum copper concentration $(2 \cdot 7 \mu \mathrm{mol} / 1 ; 17 \cdot 2$ $\mu \mathrm{g} / 100 \mathrm{ml})$ and caeruloplasmin $(0.04 \mathrm{~g} / 1 ; 0.004$ $\mathrm{g} / 100 \mathrm{ml}$ ) confirmed the diagnosis. Despite the introduction of solids at 18 weeks the copper concentration remained low, and treatment with copper sulphate $(2.5 \mathrm{mg}$ daily) was started at 6 months. Treatment was stopped at 9 months, when he was both physically and developmentally normal.

When given a choline-containing vitamin preparation (Ketovite) he developed a fish odour because of the accumulation of trimethylamine. Withdrawal of this preparation at 6 weeks and substitution with a choline-free preparation (Abidec) was soon followed by disappearance of the odour. It is speculated that prematurity rather than copper deficiency was responsible for the poor activity of liver enzyme, trimethylamine oxidase.

Copper deficiency is rare in man, but has been reported in infants with malnutrition ${ }^{1}$ and after parenteral nutrition. ${ }^{2-3}$ Only recently has pure copper deficiency in infancy been documented, ${ }^{3-4}$ although for some time it had been known that copper deficiency occurs in a syndrome characterised by hypocupraemia, hypoferraemia, hypoproteinaemia, and oedema. ${ }^{5}$ In previous reports copper deficiency was found after the investigation of anaemia. This is the only report where a fracture sustained during examination of the hip joint led to the diagnosis of copper deficiency.

\section{Case report}

After a normal pregnancy a $1 \cdot 015-\mathrm{kg}$ baby boy was born at 29 weeks by spontaneous vaginal delivery to an Asian primigravida. After transient tachypnoea he developed recurrent apnoea necessitating ventilation and intravenous dextrose electrolyte solution from day 2 to day 5, formula feeds (Cow and Gate Premium) being fully established by day 8 (150 $\mathrm{ml} / \mathrm{kg}$ ). Despite treatment with theophylline, apnoea continued and on day 17 he again required ventilation and intravenous dextrose electrolyte solution, maintenance requirement $(200 \mathrm{ml} / \mathrm{kg})$ of formula only being achieved by day 23 . After a fall of $20 \%$ his birthweight was regained by one month.

The haemoglobin at birth was $14.5 \mathrm{~g} / \mathrm{dl}$ and by 2 weeks had fallen to $8.4 \mathrm{~g} / \mathrm{dl}$, when a blood transfusion was given. Two further transfusions were required at 4 and 6 weeks. Vitamins (Ketovite) were added at 16 days and iron (Sytron) at 3 weeks. When a strong smell of fish developed Abidec (cholinefree) was substituted for Ketovite and the smell soon disappeared. A subsequent challenge with Ketovite at 8 months failed to induce the odour.

At 10 weeks, during routine examination of the hip joint, a click was felt and swelling of the left leg developed soon afterwards. $X$-ray showed a subtrochanteric fracture, osteoporotic bones with periosteal reaction, and metaphyseal irregularity (Figure). Suspicion of copper deficiency led to the diagnosis at 15 weeks when the serum copper was $2.7 \mu \mathrm{mol} / 1$ and serum caeruloplasmin $0.04 \mathrm{~g} / \mathrm{l}$ (Table). Solids were introduced at 18 weeks but

Table Data obtained before and after starting treatment with copper at 24 weeks. Between 12 and 36 weeks the normal values are copper 13-27 $\mu \mathrm{mol} / \mathrm{l}$, and caeruloplasmin $20-60 \mathrm{mg} / 100 \mathrm{ml}$

\begin{tabular}{|c|c|c|c|c|}
\hline Week & $\begin{array}{l}\text { Copper } \\
(\mu \mathrm{mol} / \mathrm{l}) / \\
\text { caerulo- } \\
\text { plasmin } \\
(\mathrm{mg} / 100 \mathrm{ml})\end{array}$ & $\begin{array}{l}\text { Haemo- } \\
\text { globin } \\
(\mathrm{g} / \mathrm{dl}) / \\
\text { reticu- } \\
\text { locytes }(\%)\end{array}$ & $\begin{array}{l}\text { Leucocytes } \\
\left(\times 10^{9} / l\right) / \\
\text { neutrophils } \\
\left(\times 10^{9} / l\right)\end{array}$ & $\operatorname{Protein}(\mathrm{g} / \mathrm{l})$ \\
\hline 9 & & $\frac{9 \cdot 5}{5}$ & & \\
\hline 11 & & $\frac{11 \cdot 6}{2}$ & $\frac{6 \cdot 8}{1.7}$ & $5 \cdot 5$ \\
\hline 15 & $\frac{2 \cdot 7}{4}$ & & & \\
\hline 21 & $\frac{6.0}{9 \cdot 7}$ & & & \\
\hline 24 & $\frac{6.9}{25}$ & $\frac{12 \cdot 2}{3 \cdot 6}$ & $\frac{12 \cdot 0}{1 \cdot 2}$ & $6 \cdot 1$ \\
\hline 26 & $\frac{15 \cdot 0}{45}$ & $\frac{12 \cdot 1}{1.9}$ & $\frac{11 \cdot 6}{4.9}$ & $6 \cdot 3$ \\
\hline 33 & $\frac{20 \cdot 8}{54}$ & $\frac{12 \cdot 3}{1 \cdot 8}$ & $\frac{8 \cdot 8}{1 \cdot 1}$ & $6 \cdot 2$ \\
\hline
\end{tabular}

Conversion: SI to traditional units-copper: $1 \mu \mathrm{mol} / 1 \approx 6.37 \mu \mathrm{g} / 100 \mathrm{ml}$. Traditional to SI units-caeruloplasmin: $1 \mathrm{mg} / 100 \mathrm{ml} \approx 10 \mathrm{mg} / 1$. Protein: $1 \mathrm{~g} / 1 \approx 0.1 \mathrm{~g} / 100 \mathrm{ml}$. 


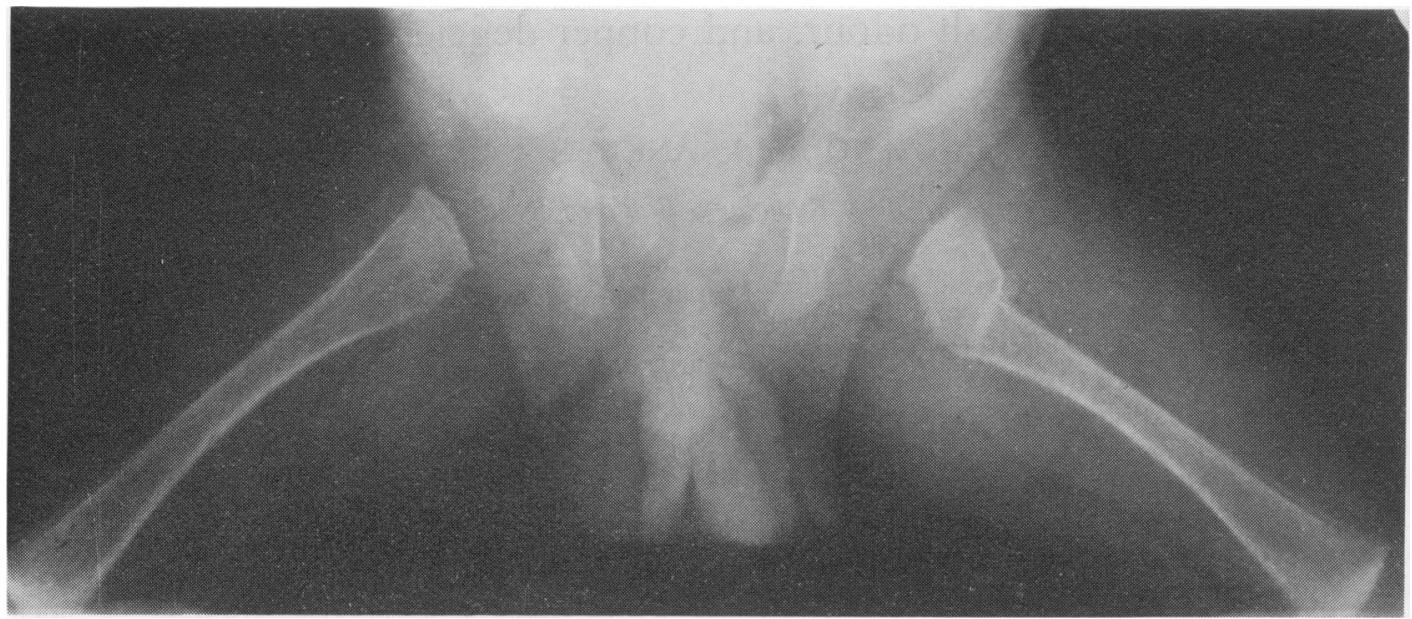

Figure X-ray of hip joints at 10 weeks showing osteoporotic femora, periosteal reaction, and metaphyseal irregularity. A subtrochanteric fracture is present on the left.

copper concentration remained low and at 24 weeks treatment started (copper sulphate $2.5 \mathrm{mg}$ daily). The effect of treatment on serum copper and other values is shown in the Table. When treatment was stopped at 9 months he was thriving and developmentally normal.

\section{Discussion}

Copper is a known constituent of many essential enzymes and deficiency in infancy is characteristically associated with haematological and skeletal changes. Unlike the blood changes, the bone changes in copper deficiency are similar to Menkes's syndrome (copper absorption defect), while the mental and other changes in Menkes's syndrome are not present.

The bone changes in our patient were osteoporosis, periostitis, and metaphyseal spur formation, changes similar to scurvy and probably arising from the need for copper to convert ascorbic acid to its active form. ${ }^{4}$ The blood changes were anaemia, leucopenia, and neutropenia $\left(<1.5 \times 10^{9} / 1\right.$ cells $)$. Neutropenia is usually the first and sometimes the only manifestation of copper deficiency. ${ }^{1}$

Previous reports of copper deficiency have affected small (under $1500 \mathrm{~g}$ ) preterm infants, who presented at 3 months with anaemia. ${ }^{3-4}$ Three preterm infants with blood and skeletal changes of copper deficiency have been described ${ }^{6}$ in whom chest $x$-rays for respiratory problems at 3 months led to its detection. We suspect the infrequency of blood and $x$-ray investigations in preterm infants after 3 months partly accounts for the apparent rarity of this condition. Two-thirds of copper stores are deposited in the last trimester, making poor storage together with inadequate intake the most likely causes of deficiency. The range of copper requirement in infancy is between 200 and $500 \mu \mathrm{g} /$ day and a reported failure $^{7}$ to induce copper deficiency in preterm infants fed a low copper formula $(15 \mu \mathrm{g} / \mathrm{kg})$ is surprising, particularly as our infant received approximately $80 \mu \mathrm{g} / \mathrm{kg}(40 \mu \mathrm{g} / 100 \mathrm{ml})$. It should however, be noted that the infants of Wilson and Lahey ${ }^{7}$ received low copper for only 2 months, and that copper absorption is determined not only by copper content but also by formula composition; for example the quantity of zinc will influence the rate of copper absorption.

This is the first report of copper deficiency with fish odour. This followed the accumulation of trimethylamine after choline ingestion and the association suggested that copper might be necessary for trimethylamine oxidase, a liver enzyme preventing trimethylamine accumulation. ${ }^{8}$ We subsequently showed that prematurity was the probable cause of poor enzyme activity. Administration of Ketovite to 3 preterm infants of similar weights and ages induced fish odour in a single infant, who was not copper deficient.

We thank Mr R Smith for help with the biochemistry and Mrs E W Hammill for typographical help.

\section{References}

1 Graham G C, Cordano A. Copper depletion and deficiency in the malnourished infant. Johns Hopkins Med J 1969 ; 124: 139-50. 
2 Karpel J T, Peden V H. Copper deficiency in long-term parenteral nutrition. J Pediatr 1972; 80: 32-6.

3 Ashkenazi A, Levin S, Djaldetti M, Fishel E, Benvinisti D. The syndrome of neonatal copper deficiency. Pediatrics $1973 ; 52$ : 525-33.

4 Al-Rashid R A, Spangler J. Neonatal copper deficiency. N Engl J Med 1971; 285: 841-3.

5 Sturgeon P, Brubaker C. Copper deficiency in infants. A syndrome characterised by hypocupremia, iron deficiency anemia, and hypoproteinemia. Am J Dis Child 1956; 92: 254-65.

6 Griscom N T, Craig J N, Neuhauser E B D. Systemic bone disease developing in small premature infants. Pediatrics 1971 ; 48: 883-95.

7 Wilson J F, Lahey M E. Failure to induce dietary deficiency of copper in premature infants. Pediatrics $1960 ; 25$ : 40-9.

8 Lee C W G, Yu J S, Turner B B, Murray K E. Trimethylaminuria: fishy odors in children. $N$ Engl J Med 1976; 295: 937-8.

Correspondence to Dr I Blumenthal, Leeds General Infirmary, Department of Paediatrics, Great George Street, Leeds LS1 3EX.

\title{
Late cerebral relapse of congenital toxoplasmosis
}

\author{
RICHARD O ROBINSON AND ROBERT J BAUMANN \\ Department of Neurology, University of Kentucky Medical Center, Lexington
}

SUMMARY Focal encephalitis occurred in a girl with activation of chorioretinitis which on clinical and serological grounds was taken to be caused by toxoplasma. The encephalitis and acute ocular inflammation resolved with treatment with pyrimethamine and sulphadiazine. This is presumably an example of reactivation of congenital cerebral toxoplasmosis.

Congenital ocular toxoplasmosis may be exacerbated years after the initial infection. ${ }^{1}$ It has been suggested that similar exacerbations of neurological toxoplasmosis occur, ${ }^{2-3}$ but these have been difficult to demonstrate. We describe an 8-year-old girl who had focal encephalitis associated with reactivation of ocular toxoplasmosis. We suggest this represents an example of reactivation of congenital central nervous system toxoplasmosis.

\section{Case report}

The patient had been born at term in eastern Kentucky after a pregnancy unmarred by maternal fever or lymphadenopathy. At 6 months strabismus had been noted, and at 3 years an optometrist diagnosed bilateral chorioretinitis. This was confirmed 2 years later by an ophthalmologist who found her bilateral visual acuity to be 20/40.

By the time she was aged 9, her school performance had deteriorated and her bilateral visual acuity was found to be 20/200. The left eye showed yellowish macular exudates with pigmentary irregularity and intraretinal oedema. A slight haze marred the overlying vitreous. Several small inactive scars lined the peripheral retina. The right eye had one large macular scar and several smaller peripheral ones, all appearing inactive. The optic discs seemed normal. The toxoplasma immunofluorescent antibody (IFA) titre was 1:64. Treatment with pyrimethamine and corticosteroids was offered but refused. She began to experience increasingly frequent headaches. Two months later she had five closely-spaced grand mal seizures. The first few were predominantly left-sided before becoming generalised. Immediately after the seizures she was afebrile, orientated, and co-operative. Her neck was supple and there were no focal neurological signs. The eye findings were similar to those described above. CSF obtained at lumbar puncture was under normal pressure but contained 100 nucleated cells (all lymphocytes) $/ \mathrm{mm}^{3}$, with a glucose concentration of $50 \mathrm{mg} / 100 \mathrm{ml}(2 \cdot 8 \mathrm{mmol} / \mathrm{l})$, protein concentration $19 \mathrm{mg} / 100 \mathrm{ml}$, and IgG concentration of $2.8 \mathrm{mg} / 100 \mathrm{ml}$. Bacterial and fungal cultures were sterile and cryptococcal antigen was absent. Her serum toxoplasma IFA titre was 1:256. An EEG 18 hours after the last seizure showed right posterior temporal 0.5 to $1 \mathrm{~Hz}$ slow wave activity, which persisted in a second EEG 4 days later. Skull and chest $x$-rays, and CAT of the head were normal. Serum VDRL and FTA were nonreactive, serum rubella titre was less than $1: 10$, serum herpes titre was less than 1:8, and cytomegalovirus titre was positive only to $1: 8$ dilution. The girl's mother had a serum toxoplasma IFA titre of $1: 256$.

The child was treated with folinic acid, sulpha- 